\title{
Exposure science in an infectious disease pandemic: who do we want to be?
}

\author{
Jane E. Clougherty $\mathbb{1}^{1}$
}

Received: 3 September 2020 / Revised: 15 September 2020 / Accepted: 25 September 2020 / Published online: 7 October 2020

(c) The Author(s) 2020. This article is published with open access

The coronavirus pandemic has been described as a "watershed moment" for exposure science [1]. Notwithstanding the clear relevance of our techniques, perhaps this pandemic is also an opportunity to reflect thoughtfully on our contribution to the greater public health effort. From March 20 through September 2, CDC recorded 96,385 new scientific citations on Covid-19-at a dizzying rate of 17,892 papers/month [2]. Perhaps this is not a moment for just more science, but rather for high-quality, targeted science supportive of current public health priorities.

The challenges of this moment are political and social, even more so than scientific. As such, we need to ask not only what we bring to the table, but, humbly, whether that contribution is genuinely helpful and relevant when nerves are frayed, and attention is scant. Is it worth, for example, complicating the story on mask selection [3, 4], potentially sowing seeds of doubt, when a huge portion of Americans already refuse to wear one? Is it helpful to raise alarm about indoor air pollution [5], when we desperately need more Americans to just stay home? While we certainly don't support opportunistic rollbacks of environmental regulation [6], can governments really curb this illness by focusing on urban air quality, rather than on the spread of the virus itself? [7]

There is no question that we have much to contribute on the benefits of exposure mitigation strategies-mask-wearing, distancing, gathering strictly outdoors-and we understand the underlying particle dynamics. But the reason exposure science has not been more prominent, I believe, is that we've too long ignored the "human" half of our "human-environment interface." The current pandemic has made the "silo"-ing of our field more apparent, and

Jane E. Clougherty

jec373@drexel.edu

1 Drexel University Dornsife School of Public Health, Philadelphia, PA, USA in forwarding our own agendas (or careers) without asking how our message may be received, and how it contributes to the greater cause, we risk muddying the waters while lives are at stake.

Each year, I tell my fresh-faced students that exposure science is the study of the "human-environment interface;" that we aim to understand, quite literally, how the environment gets under the skin. I then launch into 20 lectures on monitor allocation, Gaussian plumes, and depth-integrating samplers. Where is the 'human' in our science? Naturally, I wrap up with a week on "nonchemical stressors"- a catchall for everything outside our traditional realm-the noise that accompanies pollution sources, the poverty that drives source allocation-paying scant attention to centuries of sociology and decades of social epidemiology that came before. Further, because the term "nonchemical stressor" is self-coined (to distinguish these factors from our traditional bread-and-butter), it doesn't exist outside our realm; literature searches and reviews based on this terminology, or on selected commonly-studied stressors [8] paint us into a corner, identifying only that evidence which lies within our familiar domain — contained, knowable, safe.

The pandemic we face is mind-bogglingly complex, as human free agents make daily and hourly decisions about face-to-face interactions with other free agents. Do I go to the grocery store, or eke by one more day? Do I visit friends, outdoors, six feet apart? Can the kids visit grandma, now that they're back in school? In infectious disease, humans are both vector and subject, operating in an infinite network of free agents, all acting with imperfect and unequal (mis)information. This profoundly complex social networks [9] and health behaviors problem [10] is one that we, as exposure scientists, don't have the tools to assess. We lack the health behavior expertise to understand why people make the decisions they do, and the risk communications expertise to incentivize behavior change. We haven't tended to explore the motivations behind human behaviors, but only to record them via time-activity diaries or GPS tracking, assuming 
the sampling week is representative of any other (an assumption rendered obsolete when a pandemic upends everyone's daily routine).

I'm not arguing that exposure scientists need become social scientists, but we need to find a path out of the corner we've painted ourselves into, and be cognizant of whether and how our contribution supports the greater public health goals. We do so by following the lead of infectious disease experts, accessing expertise well outside our ranks, making friends with academics who speak a very different language, and humbly asking the simple questions. We don't know how to model social networks [9]-but sociologists do. We don't know how people make decisions under constraints [11] — but this is the stuff of economics. We don't know why someone tries on a mask-but this is what health behaviorists have dedicated their careers to [10]. Even health geography-the study of how people experience and negotiate the physical world, as relates to health [12]—offers innumerable insights, but rarely are exposure scientists in attendance at geography meetings.

Finally, we must challenge ourselves, question our own motives, and ask how any given message contributes to immediate public health needs. Muddying the waters with contradictory or under-developed data, or stealing the thunder of infectious disease experts-themselves fighting to be heard amidst a cacophony of misinformation and political gridlock [13] - is counter-productive. Perhaps it is wise and responsible for exposure science not to rush forward in a "watershed" moment, but to take a half-step back, own our supporting role, catch our breath, build some new intellectual relationships-and be better prepared for the next round. It's coming.

\section{Compliance with ethical standards}

Conflict of interest The author declares that she has no conflict of interest.

Publisher's note Springer Nature remains neutral with regard to jurisdictional claims in published maps and institutional affiliations.

Open Access This article is licensed under a Creative Commons Attribution 4.0 International License, which permits use, sharing, adaptation, distribution and reproduction in any medium or format, as long as you give appropriate credit to the original author(s) and the source, provide a link to the Creative Commons license, and indicate if changes were made. The images or other third party material in this article are included in the article's Creative Commons license, unless indicated otherwise in a credit line to the material. If material is not included in the article's Creative Commons license and your intended use is not permitted by statutory regulation or exceeds the permitted use, you will need to obtain permission directly from the copyright holder. To view a copy of this license, visit http://creativecommons. org/licenses/by/4.0/.

\section{References}

1. Deziel NC, Allen JG, Scheepers PTJ, Levy JI. The COVID-19 pandemic: a moment for exposure science. J Exposure Sci Environ Epidemiol. 2020;30:591-3.

2. Centers for Disease Control (CDC). COVID-19 research articles downloadable database. 2020. https://www.cdc.gov/library/resea rchguides/2019novelcoronavirus/researcharticles.html.

3. Fischer EP, Fischer MC, Grass D, Henrion I, Warren WS, Westman E. Low-cost measurement of facemask efficacy for filtering expelled droplets during speech. Sci Adv. 2020;6:eabd3083. https://doi.org/10.1126/sciadv.abd3083.

4. Lambert J. 4 reasons you shouldn't trash your neck gaiter based on the new mask study. 2020. https://www.sciencenews.org/a rticle/coronavirus-covid19-neck-gaiters-masks-droplets-study.

5. Nwanaji-Enwerem JC, Allen JG, Beamer PI. Another invisible enemy indoors: COVID-19, human health, the home, and United States indoor air policy. J Exposure Sci Environ Epidemiol. 2020;30:773-5.

6. U.S. Environmental Protection Agency. COVID-19 implications for EPA's enforcement and compliance assurance program. Washington, D.C.: U.S.E.P. Agency; 2020.

7. All Party Parliamentary Group Air Pollution (APPG). Air quality strategy to reduce coronavirus infection. U.K: All Party Parliamentary Group Air Pollution (APPG); 2020.

8. Lichtveld K, Thomas K, Tulve NS. Chemical and non-chemical stressors affecting childhood obesity: a systematic scoping review. J Exposure Sci Environ Epidemiol. 2018;28:1-12.

9. Exponential random graph models for social networks: theory, methods, and applications. New York, NY: Cambridge: University Press; 2013

10. Health behavior: theory, research, and practice. 5th ed. San Francisco, CA: Jossey-Bass; 2015.

11. Scott J. Chapter 9: Rational choice theory, in understanding contemporary society: theories of the present, In: Browning G, Halcli A, and Webster F, editors. SAGE Publicstions, Ltd.: Thousand Oaks, CA; 2000.

12. Dummer TJB. Health geography: supporting public health policy and planning. CMAJ. 2008;178:1177-80.

13. Yong E, The pandemic experts are not okay: many American public-health specialists are at risk of burning out as the coronavirus surges back. Emerson Collective: Washington, D.C.; 2020. 